\title{
PERANAN PENDIDIKAN ILMU PENGETAHUN SOSIALDALAM UPAYA MENCEGAH PERILAKU BULLYING SISWA (Studi Kasus di MTs Negeri 1 Kota Cirebon)
}

\author{
Nur Alifah ${ }^{1}$, Cecep Sumarna ${ }^{2}$ \\ IAIN Syekh Nurjati Cirebon ${ }^{1,2}$ \\ nuralifahlipa01@gmail.com;cecepsumarna71@gmail.com
}

\begin{abstract}
Abstrak
Berdasarkan observasi yang penulis lakukan di MTs Negeri 1 Kota Cirebon bertempat di Jalan Pilang Raya Nomor 38 Kota Cirebon diidentifikasi terdapat masalah yakni siswa-siswi di kelas VIII tersebut terindikasi sering melakukan salah satu gejala penyimpangan sosial yaitu bullying, karena peran pendidikan Ilmu Pengetahuan Sosial belum secara optimal membentuk karakter siswa yang berbudi pekerti baik. Penelitian ini bertujuan untuk memperoleh data tentang proses pembelajaran pendidikan IPS, fenomena perilaku bullying siswa di kelas, Faktor penyebab dari perilaku bullying siswa, dan Peranan dari pendidikan IPS dalam mencegah perilaku bullying siswa. Kerangka pikir dalam penelitian ini adalah perilaku bullying siswa yang terjadi saat pembelajaran IPS merupakan salah satu indikasi bahwa nilai-nilai yang terkandung dalam pendidikan IPS belum terlaksana dengan sempurna. Sehingga perlu dikaji lebih lanjut bagaimana proses pembelajaran pendidikan IPS di MTs Negeri 1 Kota Cirebon yang mampu mencegah perilaku bullying siswa, supaya dapat menghasilkan karakter siswa yang berbudi baik seperti Menghargai perbedaan yang ada; Dapat bekerjasama dengan semua siswa; dan Memiliki sikap yang bertanggung jawab, peduli, dan empati.Penelitian menggunakan metode kualitatif studi kasus dan menggunakan teknik pengumpulan data dalam penelitian ini menggunakan observasi patsisipatif, wawancara mendalam, dokumentasi.Data yang diperlukan dalam penelitian ini berupa data teoritik dan data empirik, sumber data teoritik diambil dari referensi buku-buku dan referensi lain yang sesuai dengan kajian penelitian. Data empirik diambil dari hasil kegiatan observasi, wawancara, dokumentasi yang dilakukan peneliti. Teknik analisis data melalui tiga tahap yaitu reduksi data, penyajian data, dan verifikasi data. Berdasarkan hasil penelitian dapat disimpulkan bahwa proses pembelajaran pendidikan IPS di MTs Negeri 1 Kota Cirebon sudah maksimal, terbukti dengan proses perencanaa, pelaksanaan, dan tindak lanjut yang baik dilakukan oleh guru mata pelajaran IPS kepada siswasiswinya; Perilaku bullying yang terjadi saat pembelajaran adalah bullying verbal; Faktor penyebab terjadinya bullying berasal dari faktor internal dan eksternal; Peranan nilai-nilai pendidikan IPS dalam mencegah perilaku bullying masih kurang terlaksana karena makna nilai-nilai pendidikan IPS dalam setiap sub bab materi belum dipahami oleh siswa.
\end{abstract}

\section{Kata Kunci: Pendidikan, IPS, Bullying}




\begin{abstract}
Based on the observation conducted by the writer at MTs Negeri 1 Kota Cirebon in Pilang raya street number 38 Cirebon identified that there was a problem. It was indicated that it was a trouble maker in this school. It was called bullying. it occured because the role of Social Studies was not optimally to build the students characteristics who had a good attitude. The aim of this research is to get data of social studies in learning process, phenomena of bullying, and the role of social studies to prohibit of the students bullying. The framework thinking in this research is the bullying behavior of students that occur when learning social studies is one of indication that the values contained in social studies has not been implemented perfectly. So it needs to be studied further how the learning process social studies education in MTs Negeri 1 Kota Cirebon that is able to prevent bullying behavior of students, in order to produce the character of students who are virtous good as appreciate the differences that exist; can work with all students; and has a responsible, caring, and empathetic attitude. this research used case study qualitative method and collection of the data used participative observation, deeply interview, documentation. The data of this research is teoritical and empirical data, the sources of teoritical data is taken by the books and another reference appropritiately based on the research field. Empirical data is taken by the result of observation, interview, documentation that had conducted by the researcher. Technique of data analysist are reduction, presentation/display data, dan verification. Based on this research it can be concluded that learning procss of social studies education in MTs Negeri 1 Kota Cirebon is maximal, it can be proven based on planning, acting, evaluating that was done by social studies teacher toward the students; Bullyig that happened in learning process is verbal bullying; The factor of bullying is from internal and external; The role of social studies education values to prohibit bullying does not implement because the meaning of it did not understand by the students.
\end{abstract}

\title{
Keywords: Education, Social Studies, Bullying
}

\section{A. PENDAHULUAN}

1. Latar Belakang Masalah

Perkembangan hidup manusia hakikatnya dimulai sejak lahir sampai dewasa. Perkembangan ini tak terlepas dari peran masyrakat, karena itu pengetahuan sosial dapat diakatakan bukan hal yang baru lagi untuk setiap orang. Karena setiap orang melakukan hubungan dengan lainnya dalam keluarga maupun masyarakat. Hubungan sosial yang terjadi semakin luas, dari pengalaman dan pengenalan hubungan sosial tersebut seseorang akan berkembang pengetahuannya. Pengetahuan ini melekat pada diri seseorang. Ahmadi (2011: 8) mengungkapkan bahwa segala peristiwa yang dialami dalam hidup manusia akan membentuk pengetahuan sosial dalam dirinya. 
Salah satu tantangan mendasar dalam mengajarkan pendidikan IPS adalah cepat berubahnya lingkungan sosial budaya yang merupakan wilayah kajian dari pendidikan IPS itu sendiri. Masalah ini semakin serius ketika dihadapkan pada kenyataan bahwa selama ini mata pelajaran IPS kurang mendapat perhatian. Untuk menghadapi tantangan perubahan ini sesungguhnya gurulah yang harus memandu siswa untuk membuka cakrawala sosialnya. Guru tidak lagi hanya sebagai penyampai informasi, namun juga harus bisa membimbing siswa dalam mengembangkan pengetahuan dan kemampuan sosialnya.

Undang-Undang Nomor 14 Tahun 2015 tentang Guru dan Dosen, dijelaskan bahwa Guru adalah pendidik profesional dengan tugas utama mendidik, mengajar, membimbing, mengarahkan, melatih, menilai, dan mengevaluasi peserta didik pada pendidikan anak usia dini jalur pendidikan formal, pendidikan dasar dan pendidikan menengah (Rugaiyah, 2013:6). Sehingga, pada proses pembelajaran berlangsung guru memiliki peranan yang sangat penting untuk membentuk proses pembelajaran yang nilai-nilai pengetahuan dan sikap dapat tersampaikan secara benar.

Kondisi damai atau peaceful menjadi kebutuhan setiap sekolah disetiap kelasnya. Namun, pada kenyataannya terjadi beberapa kasus yang menyebabkan sekolah tidak damai lagi para siswanya karena ada suatu tindakan bullyingdi dalam kelas itu sendiri.Masalah bullying di sekolah perlu mendapatkan perhatian khusus. Bullying merupakan salah satu bentuk tindak kekerasan pada anak yang terjadi di sekolah Perilaku bullying di dunia pendidikan saat ini sangat mengkhawatirkan. Permasalahan bullying yang terjadi di dalam kelas tidak boleh dipandang sebelah mata karena dapat berakibat fatal.

Kasus serupa terjadi di kelas VIII yang pernah peneliti ajar saat PPL (Praktek Pelaksanaan Lapangan) di MTs Negeri 1 Kota Cirebon tepatnya di kelas VIII. Seorang siswa di kelas delapan tersebut memiliki perbedaan fisik dengan teman-temannya sehingga siswa tersebut menjadi bahan ledekan teman-teman sekelasnya. Korbang bullyingdi dalam kelas berdampak pada kepercayaan diri siswa tersebut dalam pelaksanaan pembelajaran, terkadang 
siswa yang menjadi korban bullyingitu sampai menangis dan tidak mau mengikuti kegiatan diskusi pembelajaran. Perilaku bullyingjuga dilakukan dalam bentuk perkataan-perkataan yang tidak senonoh pada temannya sendiri meskipun tujuannya hanya untuk bercanda. Namun, perilaku bullying siswa dalam proses pembelajaran tidak dapat dibiarkan, apalagi terjadi saat pembelajaran IPS.

Pada hakikatnya pembelajaran IPS di Sekolah Menengah Pertama dan sederajat bersifat terpadu (integrated) yang betujuan "agar mata pelajaran ini lebih bermakna bagi peserta didik sehingga mengorganisasi materi/bahan pelajaran disesuaikan dengan lingkungan, karakteristik, dan kebutuhan peserta didik” (Sapriya,2009:48). Sehingga, diharapkan saat pembelajaran IPS berlangsung guru dan siswa dapat menerapkan nilai-nilai IPS dalam proses pembelajaran yang nyaman tanpa adanya perilaku saling membully satu sama lain.

Bullyingmerupakan suatu gejala penyimpangan sosial siswa yang terjadi di lingkungan sekolah. Bermula dari fokus masalah perilaku bullyingyang dirasa sudah mengkhawatirkan maka dilakukanlah sebuah penelitian dengan judul "Peranan Pendidikan Ilmu Pengetahuan Sosial dalam Upaya Mencegah Perilaku Bullying Siswa di MTs Negeri 1 Kota Cirebon”.

2. Rumusan Masalah

Berdasarkan latar belakang masalah diatas, maka masalah dalam penelitian ini dapat dirumuskan sebagai berikut :

a. Bagaimana proses pembelajaran pendidikan IPS di MTs Negeri 1 Kota Cirebon?

b. Bagaimana perilaku bullyingsiswa di MTs Negeri 1 Kota Cirebon?

c. Apa saja faktor yang menyebabkan siswa melakukan bullyingsaat pembelajaran IPS berlangsung?

d. Bagaimana peran nilai-nilai pendidikan IPS terhadap pencegahan perilaku bullying di MTs Negeri 1 Kota Cirebon.

3. Tujuan Penelitian

Berdasarkan permasalahan yang ada maka penelitian ini bertujuan untuk: 
a. Mengetahui proses pembelajaran pendidikan IPS di MTs Negeri 1 Kota Cirebon.

b. Mengetahui perilaku bullying siswa di lingkungan MTs Negeri 1Kota Cirebon.

c. Mengetahui alasan siswa melalakukan perilaku bullying.

d. Mengetahui peran nilai-nilai pendidikan IPS dalam mencegah perilaku bullying di MTs Negeri 1 Kota Cirebon?

\section{B. KAJIAN TEORI}

1. Pengertian Pendidikan IPS

Pengertian IPS atau Social Studies terdapat dalam buku karya Saxe yang berjudul Social Studies in Schools: A History of The early Years menurutnya adalah upaya untuk membatasi ilmu-ilmu sosial untuk penggunaan secara pedagogik. Pengertian dari Saxe ini berkembang luas dikalangan para ilmuwan Social Studies seperti dalam dokumen CSS (Commite on Social Studies) yang menyatakan bahwa Ilmu Pengetahuan Sosial merupakan bidang khusus dalam pemanfaatan ilmu-ilmu sosial sebagai tenaga dalam memperbaiki kesejahteraan umat manusia. (Sapriya, 2011: 9).

Pendidikan Ilmu Pengetahuan Sosial (IPS) merupakan salah satu mata pelajaran di sekolah yang berbasis nilai (Suwarma, 2014: 48). Pengembangan sikap dan nilai dalam IPS telah terintegrasi dalam tujuan pembelajarannya yang dikonkritkan dalam ranah kognitif, afektif, dan psikomotorik.

2. Konsep dan Tujuan Pendidikan IPS

Ilmu Pengetahuan Sosial atau disingkat dengan IPS merupakan suatu mata pelajaran wajib pada struktur Kurikulum 2013 pada jenjang pendidikan dasar SD dan SMP. Bahkan, pada Kurikulum 2006 atau yang disebut dengan Kurikulum Tingkat Satuan Pendidikan (KTSP) mata pelajaran IPS juga diajarkan oleh satuan pendidikan SMA/SMK sebagai mata pelajaran wajib dipelajari siswa yang isi kajiannya dikembangkan oleh pemeritah pusat di bidang Departemen Pendidikan dan kebudayaan (Wahidmurni, 2017: 16). 
Tujuan pendidikan IPS Menurut Ahmadi (2011: 10) diharapkan siswamemiliki kemampuan salah satunya adalah memiliki kemampuan dasar untuk berfikir logis dan kritis, rasa ingin tahu, memecahkan masalah, dan memiliki keterampilan dalam kehidupan sosial.

\section{Pengertian Bullying}

Bullying adalah sebuah perilaku yang agresif yang dilakukan oleh satu orang (individu) ataupun kelompok pada orang-orang yang dinilai lebih lemah serta dilakukan secara berulang-ulang. Semai Jiwa Amini atau SEJIWA (2008: 2) mendefinisikan bullying adalah sebuah situasi dimana terjadinya penyalahgunaan kekuatan/kekuasaan yang dilakukan oleh seseorang/sekelompok. Pihak yang kuat bukan hanya kuat secara fisik saja, namun secara mental juga. Dalam hal ini korban bullying tidak mampu membela ataupun mempertahankan dirinya karena lemah secara fisik dan mental.

Bullying merupakan perilaku yang disengaja untuk melakukan kekarasan baik secara jasmani dan rohani. Berikut ini bentuk-bentuk bullying menurut Priyatna (2010: 3) bentuk-bentuk bullying dapat dikelompokkan menjadi empat bentuk yakni pertama bullying fisikal seperti memukul, menendang, mendorog, merusak benda-benda milik korban, termasuk tindakan pencurian dan lain-lain; kedua, bullying verbal seperti mengolok-olok nama panggilan, melecehkan penampilan, mengancam, menakut-nakuti, dan lainlain;

\section{Pencegahan Perilaku Bullying}

Menurut Wiyani (2012: 98) untuk mencegah perilaku bullying di lingkungan sekolah dapat menerapkan konsep peaceful school atau sekolah yang damai. Konsep peaceful school yang diintegrasikan dengan nila-nilai yang terkandung dalam mata pelajaran IPS dapat dijadikan sebagai upaya untuk mencegah adanya perilaku bullying disekolah. Konsep peacefull school menurut Wiyani dapat mencegah perilaku bullying di sekolah dapat dicoba secara keseluruhan oleh pihak-pihak yang bertanggung jawab dalam proses pembelajaran itu sendiri. Namun, dalam pendidikan IPS itu sendiri memiliki beberapa hal yang dapat dilakukan untuk mencegah perilaku 
bullying. Sapriya (2011: 48) menjelaskan program pendidikan IPS yang komprehensif adalah program yang mencakup dimensi pengetahuan, keterampilan, nilai dan sikap, serta tindakan.

5. Kajian Penelitian yang Relevan

Hasil penelitian yang dilakukan Bibit Darmalina (2014) tentang perilaku school bullyingdi SD Negeri Grindang Kulon Progo. Berdasarkan penelitian tersebut school bullyingterjadi di SD Negeri Grindang.

a. Persamaan

Persamaan antara penelitian yang dilakukan oleh Bibit Darmalinadengan penelitian ini adalah terletak pada pembahasanperilaku bullying.

b. Perbedaan

Perbedaannya yaitu jika penelitian yang dilakukan oleh Bibit Darmalina adalah perilaku bullying yang terjadi di Sekolah Dasar (SD) sedangkan penelitian yang saya lakukan adalah meneliti perilaku bullying siswa di tingkat pendidikan Sekolah Menengah Pertama.

\section{METODOLOGI}

1. Jenis Penelitian

Penelitian ini menggunakan metode penelitian kualitatif sebagai pendekatan untuk mendapatkan pemahaman dari fenomena-fenomena dan kasus yang dipilih peneliti. Jenis penelitian ini adalah penelitian kualitatif deskriptif dengan pendekatan studi kasus. Penelitian kualitatif tidak mengutamakan besarnya populasi atau informan, bahkan populasi dan informan yang diambil sangat terbatas, karena sudah terfokuskan dengan masalah yang sudah ditentukan oleh peneliti. Jika data sudah mendalam dan cukup menjelaskan fenomena yang diteliti maka tidak perlu mencari informan lain. Menurut Bungin (2007: 68) penelitian deskriptif kualitatif bertujuan untuk menggambarkan, meringkas berbagai kondisi, fenomena, dan realitas sosial yang ada di lingkungan pendidikan yang menjadi objek penelitian. 


\section{Lokasi dan Waktu Penelitian}

Penelitian dilakukan di MTs Negeri 1Kota Cirebon. Adapun waktu pelaksanaan penelitian dari bulan Januari - Maret 2018.

3. Sumber Data

Sumber data yang didapat dari sebagai berikut :

a. Sumber data primer, yaitu data yang diperoleh secara langsung dari objek yang diteliti. Data ini dapat berupa hasil teks wawancara dan diperoleh melalui wawancara dengan informan yang sedang dijadikan sampel dalam penelitiannya.

b. Data primer dalam penelitian ini adalah data - data yang diperoleh dari WAKA kurikulum, guru mata pelajaran IPS, Guru BK, dan Siswa-Siswi MTs Negeri 1Kota Cirebon.Sumber data sekunder, yaitu data tambahan berupa informasi yang akan melengkapi data primer. Data sekunder yang peneliti peroleh dari penelitian yang telah dilakukan antara lain:

1) Dokumenatauarsipdarisekolah MTs Negeri 1 Kota Cirebon.

2) Data sekunder lain yaitu dokumentasi berupa foto-foto yang peneliti hasilkan sendiri dengan kamera digital, catatan hasilwawancara yang diperoleh peneliti saat melakukan wawancara dengan subjek dan informan penelitian serta data-data lain yang dijadikan bahan tambahan untuk mendapatkan data objek penelitian.

4. Subyek Penelitian

Subyek penelitian terfokus pada mata pelajaran IPS, WAKA kurikulumguru BK, guru mata pelajaran IPS, dan siswa-siswi kelas VIII yang terlibat dalam proses pembelajaran IPS.

5. Teknik dan Instrumen Pengumpulan Data

a. Wawancara

Responden atau informandalam wawancara ini adalah sesuai pilihan sekolah yaitu WAKA kurikulum, Guru IPS, Guru BK, dan Siswa. Guna menghindari pokok pembahasan yang panjang lebar, maka dibuatlah pedoman wawancara untuk masing-masing responden. 


\section{b. Observasi}

Observasi yang dilakukan dalam hal ini, peneliti berkedudukan sebagai participant observer, yakni peneliti turut aktif pada waktu penelitian.

c. Dokumentasi

Metode dokumentasi ini dimaksudkan untuk memperoleh data berdasarkan sumber data yang ada di sekolah.

6. Teknik Analisis Data

a. Pengumpulan data

Peneliti mencatat semua data secara objektif dan apa adanya sesuai dengan hasil observasi dan wawancara di lapangan.

b. Reduksi Data

Mereduksi data berarti merangkum, memilih hal-hal yang pokok, memfokuskan pada hal-hal yang penting dicari tema dan polanya dan membuang yang tidak perlu.

c. Display Data / Penyajian Data

Penyajian data berbentuk sekumpulan informasi yang tersusun sehingga dapat ditarik suatu kesimpulan. Penyajian data dilaksanakan agar sajian data tidak menyimpang dari pokok permasalahan.

d. Penarikan kesimpulan

Penarikan kesimpulan atau verifikasi adalah usaha untuk mencari atau memahami makna, keteraturan, pola-pola, penjelasan, alur sebab akibat atau proposisi. Verifikasi penulis lakukan setelah penyajian data selesai, dan ditarik kesimpulanya berdasarkan hasil penelitian lapangan yang telah dianalisis dengan teori.

\section{Keabsahan Data}

Menurut Moleong (2013: 321) Keabsahan data merupakan konsep penting dalam sebuah penelitian yang validitas dan realibilitasnya harus disesuaikan dengan tuntuntan pengetahuan. Keabsahan data dalam sebuah penelitian merupakan yang terpenting sebagai tolak ukur penelitian tersebut relevan antara teori dan permasalahan di lapangan. 


\section{HASIL PENELITIAN DAN PEMBAHASAN}

Penelitian ini dilakukan untuk mengetahui peranan dari pendidikan IPS dalam mencegah perilaku bullying di MTs Negeri 1 Kota Cirebon.Berdasarkanhasil penelitian ini adalah proses pendidikan IPS di MTs Negeri 1 Kota Cirebon dilaksanakan sesuai dengan kurikulum yang berlaku. Kurikulum yang digunakan dalam proses pembelajaran adalah kurikulum 2013 atau biasa disebut dengan KURTILAS. Tenaga pengajar pendidikan IPS itu sendiri linier dengan latar belakang pendidikan IPS, sehingga dalam penyampaian materi guru dapat menguasainya dengan baik. Model pembelajaran yang diterapkan sangat bervariatif. Setiap guru IPS memiliki karakteristik yang berbeda dalam pemanfaatan model pembelajaran. Hal ini disebabkan karena tingkat inovasi dan kreatifitas guru disesuaikan dengan kondisi siswa itu sendiri. Hambatan yang dirasakan guru dalam mata pelajaran IPS adalah rendahnya minat motivasi belajar siswa sehingga tuntutan belajar aktif dan mandiri dalam KURTILAS sering tidak terlaksana. Siswa belum terbiasa secara aktif mencari permasalahan. Namun, untuk mengatasi hambatan tersebut guru IPS melakukan beberapa stimulan kepada siswa supaya dapat aktif dalam proses pembelajaran terutama untuk bertanya.

Hasil pengamatan peneliti menunjukkan bahwa pada mata pelajaran Pendidikan Ilmu Pengetahuan Sosial (IPS) telah menggunakan KURTILAS (kurikulum dua ribu tiga belas) yang menyeluruh dari kelas VII, VIII, dan IX. Pada tahun ajaran 2016/2017 penggunaan KURTILAS di MTs Negeri 1 Kota Cirebon belum merata, yakni hanya dilaksanakan pada kelas VII dan VIII. Namun, untuk tahun ajaran sekarang 2017/2018 sudah terlaksana penggunaan KURTILAS dari kelas VII sampai IX. Semua itu terlaksana atas kegigihan dan ketelatenan dari petugas pelaksana pendidikan di MTs Negeri 1 Kota Cirebon. Pelaksanaan kurikulum yang tidak serentak tersebut didasarkan karena belum lengkapnya sumber bahan ajar dan kesiapan dari berbagai pihak. Kurikulum tersebut merupakan kurikulum berbasis kompetensi. Demikian pula penilaian didapat dari semua aspek yaitu kognitif, psikomotorik, dan afektif. Pengambilan nilai ini tidak hanya bersumber dari hasil ujian saja, melainkan dilihat dari nilai kesopanan, sikap, religi, dan kedisiplinan siswa itu sendiri. 
Fenomena perilaku bullying di kalangan siswa MTs Negeri 1 Kota Cirebon khususnya di kelas VIII D meruakan jenis perilaku bullying verbal yang terjadi saat proses pembelajaan berlangsung.Guru berpendapat perilaku kenakalan atau kekerasan di kelasnya dalam batas wajar dan merupakan sesuatu yang normal dalam perkembangan siswa. Guru masih belum memahami maksud dari bullying sebenarnya, terbukti ketika peneliti melontarkan pertanyaan tentang bullying itu sendiri kepada guru-guru yang terlibat dalam penelitian ini hanya guru BK yang memahami maksud dari bullying. Sehingga peneliti harus memberikan padanan kata dalam bahasa Indonesia yaitu kenakalan atau kekerasan. Kebanyakan guru mengartikan bullying itu sebatas ejekan yang terjadi di dunia maya seperti media sosial facebook. Siswa AG terbiasa membully AF dengan melontarkan beberapa ejekan, meledek, dan penggunaan kata kasar atau tak pantas. Bullying verbal ini dilakukan ketika adanya kelengahan pengawasan guru. perilaku bullying dalam lingkungan sekolah menegah pertama dianggap sebagai kenakalan yang wajar dilaukan untuk usia remaja. Mereka menganggap bullying merupakan bagian dari perkembangan remaja tersebut dan akan berhenti dengan sendirinya. Padahal, bullying dari sudut pandangan psikologi merupakan sebuah tindakan yang termasuk kedalam agresi. Agresi adalah kekerasan yang dilakukan secara sengaja baik secara fisik maupun psikis. Bullying sendiri adalah sebuah tindakan penindasan atau kekerasan baik secara verbal atau fisik yang terjadi secara berulag-ulang kepada korban yang dianggap lemah.

Berdasarkan hasil pengamatan penelitian menunjukkan bahwa penyebab perilaku bullying siswa dipengaruhi beberapa faktor. Jika dilihat dari hasil tabel di bawah ini menunjukkan ada faktor eksternal dan internal pelaku dalam melakukan bullying. Faktor eksternal pelaku didapatkan dari pergaulan dengan teman-teman dari kelas yang berbeda ketika di luar proses pembelajaran, kurang pedulinya siswa jika ada korban bullying, dan lemahnya pengawasan guru ketika proses pembelajaran. Sedangkan, faktor internal didapatkan dari kecenderungan sifat pelaku yang sangat ingin diperhatikan dan diakui keberadaannya di kelas, merasa paling kuat dan sempurna, serta kondisi keluarga yang tidak utuh. 
Maraknya perilaku bullyingdi kelas VIII D yang dilakukan oleh AG selalu terjadi, hal ini karena sebagian guru masih menganggap bullying sebagai kenakalan remaja. Bulying diyakini oleh beberapa guru merupakan bagian dari sebuah perkembangan remaja. Faktanya, bullying merupakan sebuah gejala penyimpangan sosial yang jika dibiarkan dapat merujuk pada sebuah tindakan kriminal. Jensen dalam Sarwono (2012: 255) menjelaskan banyak sekali faktor yang menyebabkan kenakalan remaja maupun kelainan perlaku remaja lainnya. Berbagai teori yang menjelaskan penyebab kenakalan remaja, yang sesuai dengan fakta di lapangan adalah merujuk pada salah teori Jensen yaitu Differential Association. Menurut teori ini kenakalan remaja adalah akibat salah pergaulan. Anak-anak nakal karena bergaulnya dengan anak nakal juga.

Penyebab perilaku bullying di kalangan siswa dari hasil observasi dan wawancara menunjukkan faktor yang sangat beragam. Faktor-faktor tersebut tidak terlepas dalam kehidupan sekitar siswa itu sendiri, diantaranya adalah:

1. Faktor keluarga. Kondisi pelaku yang kurang mendapatkan kehangatn kasih sayang dan rendahnya perhatian yang didapatkan, serta kurangnya pengawasan dari orang tua.

2. Faktor internal. Faktor internal ini berasal dari dalam diri pelaku seperti karakter yang tidak terlalu peka, sosialisasi pertemanan yang salah, dan ingin mendaptkan perhatian dari siswa lainnya.

3. Faktor pergaulan. Pelaku yang terbiasa melakukan bullying terpengaruh dengan teman terbiasa melakukan bullying, dan bergaul dengan anak yang suka betindak kekerasan.

Pendidikan IPS merupakan ilmu yang berbasis kemanusiaan. Eksistensi dari pendidikan IPS dianggap mampu untuk mencegah perilaku bullying. Nilainilai yang terkandung dalam pendidikan IPS mengajarkan siswa untuk saling bekerjasama satu sama lain dan memberikan bekal keterampilan dalam berhubungan sosial di lingkungan masyarakat. Penyampaian nilai-nilai yang terkandung dalam IPS dapat diterima dengan baik jika antara guru dan siswa memiliki hubungan yang harmonis dan selaras. Proses pembelajaran IPS yang dilakukan di kelas VIII D efektif untuk mencegah perilaku bullying ketika guru menerapkan model pembelajaran TPS (Think, Pair, and Share). Model tersebut 
menuntut siswa untuk mencari pasangan dalam pembelaran kemudian mencari informasi informasi sebanyak mungkin untuk mencapat target tugas yang telah diberikan guru. Siswa yang terbiasa melakukan bullying AG tidak sempat melakukan bullying kepada AF karena disibukkan dengan kegiatan tersebut. Namun, pencegahan melalui penggunaan variasi model pembelajaran dalam IPS hanya bersifat sementara. Saat pertemuan selanjutnya ketika guru menerapkan model yang berbeda perilaku bullying terus dilakukan. Sehingga, dengan demikian peranan dari pendidikan IPS untuk mencegah perilaku bullying belum sempuran.

\section{E. KESIMPULAN DAN SARAN}

1. Kesimpulan

Berdasarkan hasil penelitian yang peneliti lakukan, maka dapat disimpulkan data dan uraian sebagai berikut :

a. Berdasarkan hasil data-data dari hasil wawancara dan penelitian yang peneliti lakukan mengenai proses pembelajaran pendidikan IPS di MTs Negeri 1Kota Cirebon semua Guru IPS sepakat mengatakan bahwa sudah maksimal.

b. Siswa sering melakukan bullying antar temannya dalam bentuk bullying verbal dan non verbal.

c. Faktor yang menyebabkan munculnya bullying pada siswa dikarenakan timbul dari dorongan dalam diri siswa supaya dapat diterima dan diakui teman sekelasnya serta lemahnya pengawasan (eksternal).

d. Peranan dari nilai-niai yang terkandung dalam pendidikan IPS belum secara optimal dapat mencegah bullying.

2. Saran

a. Bagi siswa, hendaknya dapat berteman dengan siapapun tanpa membeda-bedakan fisik seseorang. Karena bagaimanapun manusia adalah makhluk sosial yang saling membutuhkan antara satu sama lain. Sebaiknya siswa dapat memiliki rasa empati untuk dapat merasakan posisi sebagai korban bullying dan rasa percaya diri dalam berteman 
dengan siapapun tanpa meyakiti satu sama lain dan jangan membalas bullying dengan bullying.

b. Bagi guru, sebaiknya lebih memperdulikan kebutuhan psikis siswa jangan hanya kebutuhan kognitif yang selalu diprioritaskan. Guru harus senantiasa mengawasi perilaku siswanya. Pengawasan bukan hanya berlaku di dalam kelas melainkan ketika di luar kelas.

c. Bagi guru IPS, hendaknya lebih fokus lagi untuk melatih siswa dalam berinteraksi dan berhubungan sosial dalam setiap materinya.

\section{DAFTAR PUSTAKA}

Ahmadi, Iif Khoiru dan Sofan Amri. 2011. Metode Pembelajaran IPS Terpadu. Jakarta: Prestasi Pustakaraya.

Bungin, Burhan. 2007. Penelitian Kualitatif: Komunikasi, Ekonomi, Kebijakan Publik, dan Ilmu Sosial Lainnya. Jakarta: Kencana.

Darmalina, Bibit. 2014. "Perilaku School Bullying di SD Negeri Grindang, Hargomulyo, Kokap, Kulon Progo Yogyakarta”. Skripsi. Yogyakarta. Fakultas Ilmu Pendidikan Universitas Negeri Yogyakarta.

Moleong, J. Lexy. 2013. Metodologi Penelitian Kualitatif. Bandung: Remaja Rosdakarya.

Priyatna, Andri. 2010. Let's End Bullying: Memahami, Mencegah, dan Mengatasi Bullying. Jakarta: Elex Media Komputindo.

Rugaiyah dan Atiek Sismiati. 2013. Profesi Kependidikan. Bogor: Ghalia Indonesia.

Sapriya. 2011. Pendidikan IPS Konsep dan Pembelajaran. Bandung: Rosdakarya.

Suwarma, Al-Muchtar. 2014. Inovasi dan Transformasi Pembelajaran Pendidikan IPS. Bandung: Gelar Pustaka Mandiri.

Tim Yayasan Semai Jiwa Amini (SEJIWA). 2008. Bullying: Mengatasi Kekerasan di Sekolah dan Lingkungan. Jakarta: Grasindo.

Wahidmurni. 2017. Metodologi Pembelajaran IPS. Yogyakarta:Ar-Ruzz Media.

Wiyani, NovanArdy. 2012. Save Our Children From School Bullying. Yogyakarta: Ar-Ruzz Media. 